\title{
Experimental evaluation of anti-hyperglycemic and hypolipidemic effects of stevia rebaudiana, Anacardium occidentale on wistar rats
}

\author{
Brijesh K. ${ }^{*}$, Kamath $\mathbf{M}^{2}$
}

${ }^{1}$ Reader, Department of Agadatantra, Government Akhandanand Ayurved College, Ahmedabad, Gujarat, India ${ }^{2}$ Associate professor, Division of Ayurveda, center for Integrative Medicine and Research (CIMR), Manipal University, Manipal, Karnataka, India

Received: 21 August 2016 Accepted: 24 September 2016

*Correspondence to:

Dr. Brijesh K,

Email: ayurbrijesh@gmail.com

Copyright: (c) the author(s), publisher and licensee Medip Academy. This is an openaccess article distributed under the terms of the Creative Commons Attribution NonCommercial License, which permits unrestricted noncommercial use, distribution, and reproduction in any medium, provided the original work is properly cited.

\begin{abstract}
Background: Diabetes mellitus, obesity, hypertension, hyperlipidaemia etc. is one of the pandemic metabolic disorder in the world, may lead to obesity, hypertension, hyperlipidaemia etc. Despite of medical advances like oral hypoglycemic agents, insulin pump, xenotransplantation and all don't provide enough control of blood sugar level to control Diabetes and its complications. Hence it is the right time for work on a new medicine, which can successfully control the blood sugar and bodily lipids and cost effective one also. In the present study an attempt is made to check the efficacy of folklore drugs with a conventional anti-diabetic compound glibenclamide.
\end{abstract}

Methods: The decoction of a drugs Stevia rebaudiana and Anacardium occidentale prepared as described in The Ayurvedic Formulary of India, wistar rats of either sex were selected randomly. Before and after values of blood glucose, triglyceride, high density lipid and total cholesterol level were taken.

Results: On analyzing the results, the study showed that the trial drug II stevia is effective and trial drug I Kajutaka is slightly effective in reducing the glucose level next to glibenclamide. The trial drug I Kajutaka showed effective in reducing the Triglyceride level followed by Stevia. The action may be due to alkaloids such as Stevioside, Rebaudioside possessed by Stevia, which may stimulate the islets of the pancreas to release Insulin. The Hypolipedimic action may be due to presence of Chemical constituents in Kajutaka leaf such as Ascorbic acid and Niacin.

Conclusions: The present experimental study is preliminary one elaborate study with larger sample size is required to come up with a more significant result.

Keywords: Anacardiumoccidentale, Diabetes mellitus, Hyperglycaemia, Pancreas, Stevia rebaudiana

\section{INTRODUCTION}

Positive health means physical, mental and socioeconomic well-being one. But now days a paradigm shift is observed from non-communicable disorders. Non communicable disorders mainly comprise obesity, hypertension and diabetes. Diabetes is not only psychological but it is metaphysical as well as metabolic disorder one also. ${ }^{1}$ Diabetes mellitus is considered as a disease of modern civilization may affect $4.4 \%$ population in 2030, in view of its widespread and increased incidence, it is currently considered as a social disease, which requires undertaking a number of public measures. ${ }^{2}$ Diabetes is mainly a syndrome associated with, oxidative stress, hyperglycemia, polyuria, ketosis etc. $^{3}$

Diabetes now a day engulfs millions of people throughout the world, easily controlled with medicine and diet. The treatment of diabetes with herbal drugs is in vogue. Educated people have started the search for some alternates which are safe in the prevention of Diabetes Mellitus. In this study, two medicinal plants stevia rebaudiana and Anacardium occidentale are used to evaluate their anti-diabetic as well as hypolipidemic property also, S.rebaudiana an exotic drug in India. S.rebaudiana used by Paraguay tribal people, while another drug A.occidental leaf was used as a folklore 
drug in the tribal people of Brazil for diabetes. In Nigeria, its decoction of root and stem is used as antidiarrheal as well as anti-inflammatory one and it possesses antidiabetic property also., ${ }^{4,5}$ The drugs are taken for this study with the aim of evaluating and establishing the hypoglycemic effect and to check the action of drugs on Triglyceride, HDL, and Total Cholesterol in the animal model developed by giving high Fructose diet.

The components responsible for the sweet properties of the plant Stevia are glycosides of steviol, primary stevioside (ent-13-hydroxykaur-16-en-18-oic acid), which is 250-300 times sweeter than sucrose and rebaudioside. Stevioside and steviol have been subjected to extensive genetic testing. Toxicological assessments of stevioside suggest that it is a relatively safe compound. The majority of positive genetic toxicology studies involve bacterial mutation with steviol. ${ }^{6}$ It is recommended for Diabetes and has been extensively tested on animals and has been used by humans with no side effects. ${ }^{7}$ Among the bacterial species maximum inhibition was found in S. aureus, followed Streptococcus mutans, B. subtilis and E. coli. The crude leaf chloroform extract of $S$. rebaudiana leaves was also found to be effective than aqueous extract for all the bacteria tested. Maximum inhibition on the comparative scale was found in S. aureus, S. mutans, B. subtilis followed by E. coli. This may be possible that the secondary metabolite "stevioside" is responsible for the antimicrobial activity Chronic administration of a crude extract for 40 and 60 days induced hypotension, diuresis, and natriuresis with glomerular filtration rate (GFR) constant. ${ }^{8}$ The results suggest that oral administration to rats of an aqueous extract of Stevia dried leaves induce systemic and renal vasodilation, causing hypotension, diuresis, and natriuresis. ${ }^{9}$ It was shown that $5 \%$ water decoction of stevia leaves reduced the fertility of female rats by about $65 \%$.

Stevia rebaudiana and Anacardium occidentale was long known to the Guarani Indians of the Paraguayan highlands who called it caá-êhê, meaning "Sweet herb". The leaves were used either to sweeten maté or as a general sweetening agent. ${ }^{10}$ The plant's extract shows that it contains saponin, phenolics, flavonoids, vitamins, and selenium. Research reveals that the methanolic extract of A. occidentale exhibits properties like regeneration of beta cells as well as hyperglycaemia. A.occidentale contains alkaloids, flavonoids, tannins, saponins and chemically contain $\alpha$-glucosidase inhibitors, kampferol, quercetol, rthamnosides $\alpha$-glucosidase inhibitors prevent $\alpha$-glucosidase in the GIT, while kaempferol stimulates insulin secretion. ${ }^{11-13}$

\section{METHODS}

\section{Preparation of the trial drugs}

The Decoction is prepared from the fresh leaves of S.rebaudiana and A.occidentale of are collected are collected, out of which $25 \mathrm{gms}$ of the drug was taken to which 8 parts i.e. $200 \mathrm{ml}$ of water was added and boiled in low fire and reduced to $1 / 4^{\text {th }}$ part. Dose fixed as per the generalized dose for the animals has been calculated based on the conversion formula rat dose $=0.018 \mathrm{X}$ Human Dose X 5/Kg body wt. All the above preparations were administered according to this formula. In the present study Control group [G1] - not received any medication, Standard drug Glibenclamide [G2] is administered in the form of Suspension. The dosage is fixed as $0.5 \mathrm{mg} / \mathrm{kg}$ body wt orally. The Trial drug I [G3] A.occidentale and Trial drug II [G4] S.rebaudiana is to be administered in the form of decoction. The dosage is fixed as $4.5 \mathrm{ml} / \mathrm{kg}$ body wt orally.

\section{Experimental study}

Selection of experimental model: High Fructose Diet induced (HFD) induced diabetes model

The total duration of study was 50 days.

(20 Days High Fructose Diet +30 Days administration of trial drugs)

Wistar rats of either sex weighing in between 150$200 \mathrm{gms}$ were selected randomly. The rat was selected because Blood Glucose, Triglyceride, High-Density Lipid and Total Cholesterol Level are identical in Human beings physiologically and pathologically. The rat being omnivorous resembles a man nutritionally and hence is used for the study. The rats are anesthetized and blood is drawn from the inner canthus of the eye by puncturing the orbital artery with the help of heparinized capillary tube.

A set of 50 Wistar rats is selected in which two rats were placed in a cage and fed with Fructose diet for a period of 20 days. On 21 st day the blood investigation will be done and the rats with increased Triglyceride levels will be selected and divided into 4 groups consisting of 6 rats in each group. From $21^{\text {st }}$ day till 50th day the drugs will be given to the particular group.

Table 1: Experimental protocol.

\begin{tabular}{|c|c|c|c|}
\hline Group & Treatment dose & Duration & OGTT test \\
\hline $\begin{array}{l}\text { Control } \\
\text { group } \\
\text { [G1] }\end{array}$ & $\begin{array}{l}\text { Maintained on } \\
\text { normal control diet }\end{array}$ & 30 Days & \multirow{4}{*}{$\begin{array}{l}\text { Done on the } \\
35^{\text {th }} \text { day by } \\
\text { giving } \\
\text { glucose at } \\
\text { the dose of } \\
2 \mathrm{gm} / \mathrm{kg} \\
\text { body wt and } \\
\text { checking } \\
\text { glucose level } \\
\text { of all the } \\
\text { four groups } \\
\text { at } \\
0 \text { and } 2 \mathrm{hrs} \text {. }\end{array}$} \\
\hline $\begin{array}{l}\text { Standard } \\
\text { Group } \\
{[\mathrm{G} 2]}\end{array}$ & $\begin{array}{l}\text { Glibenclamide } \\
0.5 \mathrm{mg} / \mathrm{kg} . \text { body.wt. }\end{array}$ & 30 Days & \\
\hline $\begin{array}{l}\text { Trial } \\
\text { Group I } \\
\text { [G3] }\end{array}$ & $\begin{array}{l}\text { Ancardium } \\
\text { decoction } \\
4.5 \mathrm{ml} / \mathrm{kg} . \text { body } \mathrm{wt} .\end{array}$ & 30 Days & \\
\hline $\begin{array}{l}\text { Trial } \\
\text { Group II } \\
{[\mathrm{G} 4]}\end{array}$ & $\begin{array}{l}\text { Stevia decoction } \\
4.5 \mathrm{ml} / \mathrm{Kg} \text { body } \mathrm{wt} \text {. }\end{array}$ & 30 days & \\
\hline
\end{tabular}


The rats fasted overnight on 34th day and water was given ad libitum. On the $35^{\text {th }}$ day in order to know the efficacy of the drug (after the $15^{\text {th }}$ day of drug administration) the Glucose is given at the dose of 2 $\mathrm{gm} / \mathrm{kg}$ body wt and the blood glucose level is checked at $0 \mathrm{hrs}$ and oral glucose was given and tested once again after 2 hrs.

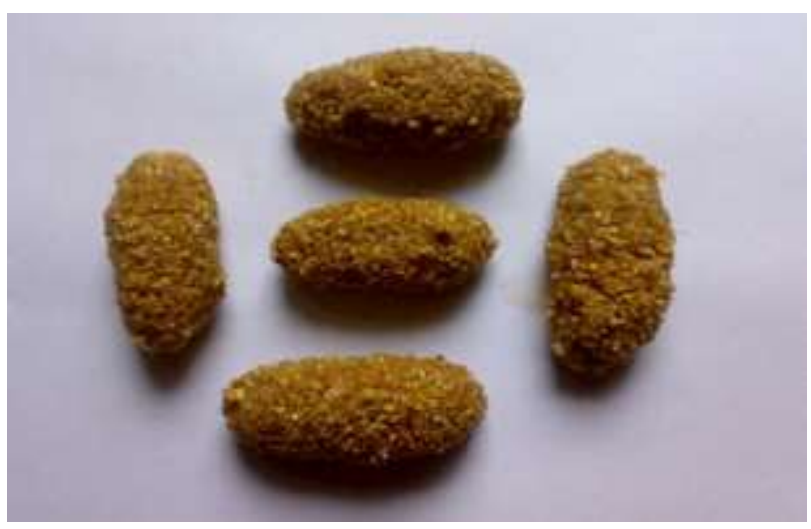

Figure 1: High fructose diet.

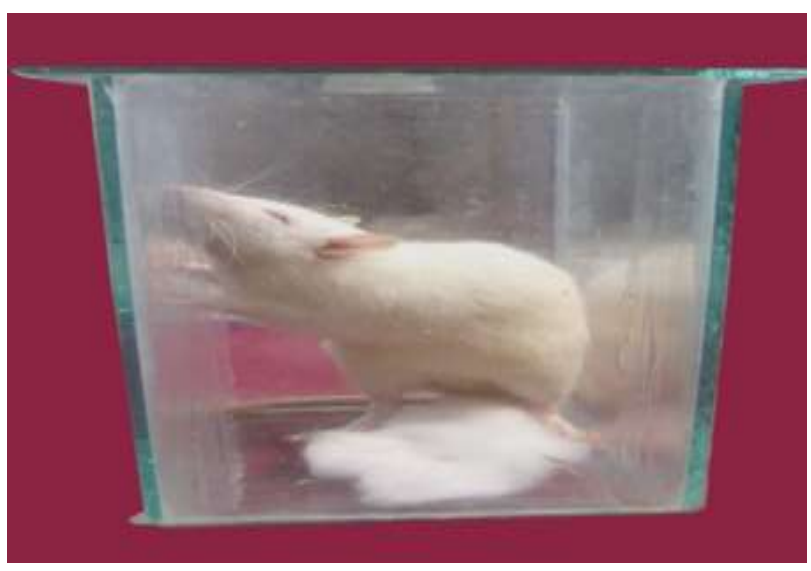

Figure 2: Rats anesthezied with ether.

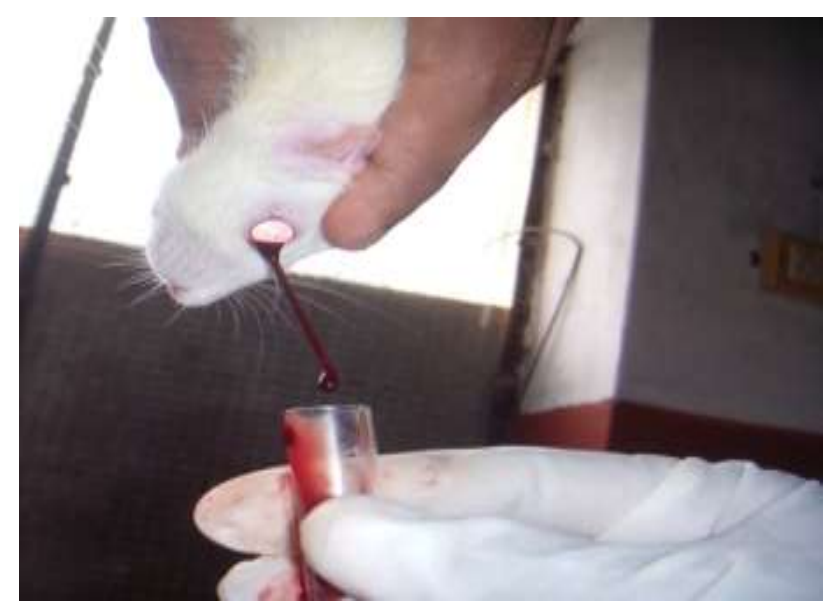

Figure 3: Withdrawal of blood.

On the $50^{\text {th }}$ day in order to know the values of Fasting Blood Sugar, Triglycerides, High-Density Lipid and
Total Cholesterol the blood is withdrawn from all the groups. The obtained values of different groups will be subjected to statistical analysis to evaluate the Antidiabetic activity (Table 1, Figure 1, 2, 3).

\section{RESULTS}

\section{Statistical method}

One way ANOVA followed by Scheffe's Post-hoc test using the SPSS-16 software.

After 30 days of drug administration statistically the following results were found on different parameters:

\section{OGTT- Oral glucose tolerance test on $35^{\text {th }}$ day}

The standard drug Glibenclamide showed a significant decrease in the Glucose level. The trial drug ii stevia showed a less significant in decreasing the glucose level when compared to the standard group. The trial drug I ancardium shows a mild decrease in the glucose level when compared to standard group and trial group II stevia (Table 2).

Table 2: Mean values of Oral Glucose Tolerance Test in all the groups $\left[35^{\text {th }}\right.$ day $]$.

\begin{tabular}{|lll|}
\hline Group & Glucose at $\mathbf{0}$ hrs & Glucose at $\mathbf{2}$ hrs \\
\hline $\begin{array}{l}\text { Control group } \\
\text { [G1] }\end{array}$ & 101.666 & 123.666 \\
\hline $\begin{array}{l}\text { Standard } \\
\text { group [G2] } \\
\text { Glibenclamide }\end{array}$ & 102.166 & 116.500 \\
\hline $\begin{array}{l}\text { Trial drug I } \\
\text { [G3] }\end{array}$ & 102.333 & 121.833 \\
Anacardium & & \\
\hline $\begin{array}{l}\text { Trial drug II } \\
\text { [G4] Fasting } \\
\text { Blood Sugar }\end{array}$ & 100.333 & 117.666 \\
\hline
\end{tabular}

Table 3: Fasting blood glucose [FBS - mg/dl] data of all the groups in Wistar rats.

\begin{tabular}{|llll|}
\hline Group & $\begin{array}{l}\text { No. of } \\
\text { rats }\end{array}$ & \multicolumn{2}{l|}{ FBS - mg/dl [Mean+SEM] } \\
\hline $\begin{array}{l}\text { Control group } \\
\text { [G1] }\end{array}$ & 6 & $107.33 \pm 2.46$ & $99.33 \pm 2.47^{\mathbf{b , d}}$ \\
\hline $\begin{array}{l}\text { Standard } \\
\text { group [G2] }\end{array}$ & 6 & $106.33 \pm 2.60$ & $65.33 \pm 2.72^{\mathbf{a , c}}$ \\
$\begin{array}{l}\text { Glibenclamide } \\
\text { Trial- I [G3] }\end{array}$ & 6 & $101.50 \pm 2.92$ & $98.83 \pm 2.69^{\mathbf{b , d}}$ \\
$\begin{array}{l}\text { Kajutaka } \\
\text { Anacardium }\end{array}$ & 6 & $108.00 \pm 2.58$ & $74.83 \pm 2.56^{\mathbf{a , c}}$ \\
\hline $\begin{array}{l}\text { Trial-II [G4] } \\
\text { Stevia }\end{array}$ & 6 & & \\
\hline
\end{tabular}




\section{FBS}

The Standard drug glibenclamide shows significant $(\mathrm{P}<0.05)$ reduction in FBS level when compared to other groups. The trial drug II stevia shows significant $(\mathrm{P}<0.05)$ reduction if FBS level when compared to Trial drug I Ancardium (Table 3).

\section{Additional investigations}

\section{Triglycerides}

The Trial drug I Ancardium shows a significant $(\mathrm{P}<0.05)$ reduction in Triglycerides level when compared to Standard group and Trial drug II Stevia. The Trial drug II Stevia shows a Significant $(\mathrm{P}<0.05)$ reduction in Triglycerides level when compared to Standard group (Table 4).

Table 4: Triglyceride [TG] data of all the groups in wistar rats.

\begin{tabular}{|c|c|c|c|}
\hline \multirow[b]{2}{*}{ Groups } & \multirow{2}{*}{$\begin{array}{l}\text { No. } \\
\text { of } \\
\text { Rats } \\
\end{array}$} & \multicolumn{2}{|c|}{ TG - mg/dl [Mean \pm SEM] } \\
\hline & & Day-21 & Day-50 \\
\hline $\begin{array}{l}\text { Control group } \\
\text { [G1] }\end{array}$ & 6 & $176.33 \pm 8.44^{\mathrm{c}, \mathrm{d}}$ & $169.83 \pm 7.52^{\mathrm{d}}$ \\
\hline $\begin{array}{l}\text { Standard } \\
\text { group [G2] } \\
\text { Glibenclamide }\end{array}$ & 6 & $192.00 \pm 2.54^{\mathrm{d}}$ & $184.00 \pm 2.42^{\mathrm{d}}$ \\
\hline $\begin{array}{l}\text { Trial-I [G3] } \\
\text { Kajutaka } \\
\text { Anacardium }\end{array}$ & 6 & $212.33 \pm 9.85^{\mathrm{a}, \mathrm{d}}$ & $187.67 \pm 9.16^{\mathrm{d}}$ \\
\hline $\begin{array}{l}\text { Trial-II [G4] } \\
\text { Stevia }\end{array}$ & 6 & ${ }_{c}^{296.00 \pm 8.77^{a-}}$ & $\begin{array}{l}277.83 \pm 8.72^{a-} \\
c\end{array}$ \\
\hline
\end{tabular}

\section{High-Density Lipid}

There was no significant difference between the four groups in reducing the HDL level (Table 5).

Table 5: High density lipid [HDL] data of all the groups in wistar rats.

\begin{tabular}{|llll|}
\hline & $\begin{array}{l}\text { No. of } \\
\text { rats }\end{array}$ & \multicolumn{2}{l|}{$\begin{array}{l}\text { HDL - mg/dl } \\
{[\text { Dean } \pm \text { SEM] }}\end{array}$} \\
\hline $\begin{array}{l}\text { Control group } \\
{[\text { G1] }}\end{array}$ & 6 & $31.17 \pm 2.06$ & Day-50 \\
\hline $\begin{array}{l}\text { Standard group } \\
{[\text { G2] }}\end{array}$ & 6 & $35.00 \pm 3.84$ & $31.00 \pm 3.56$ \\
Glibenclamide & 6 & $40.50 \pm 2.25$ & $32.17 \pm 1.28$ \\
\hline $\begin{array}{l}\text { Trial-I [G3] } \\
\text { Kajutaka } \\
\text { Anacardium }\end{array}$ & 6 & $42.50 \pm 2.64$ & $32.17 \pm 1.01$ \\
\hline $\begin{array}{l}\text { Trial-II [G4] } \\
\text { Stevia }\end{array}$ & 6 & & \\
\hline
\end{tabular}

\section{Total cholesterol}

The trial drug II and trial drug I show a slight significance in reducing the total cholesterol level when compared to control group and standard group (Table 6).

The Control group is not significant in reducing Fasting Blood Sugar, Triglycerides, High-Density Lipid, and Total Cholesterol when compared to other three groups statistically. In case of OGTT (Oral Glucose Tolerance Test) the standard drug Glibenclamide showed a significant decrease in the Glucose level compared to $\mathrm{S}$. rebaudiana, while A. occidentale shows a mild decrease in the Glucose level when compared to Standard group and Stevia. In the case of FBS, the Standard drug Glibenclamide shows significant $(\mathrm{P}<0.05)$ reduction in FBS level when compared to other groups. But in the case of Triglycerides trial drug A. occidentale shows a significant $(\mathrm{P}<0.05)$ reduction in Triglycerides level when compared to standard and S.rebaudiana. While S.rebaudiana shows a significant action compared to standard group. In case of High-Density Lipid there was no significant difference between the four groups. It was observed that both trial drug shows slight significance in reducing the Total Cholesterol level when compared to control group and standard group.

Table 6: Total cholesterol data of all the groups is wistar rats.

\begin{tabular}{|llll|}
\hline Groups & $\begin{array}{l}\text { No. of } \\
\text { Rats }\end{array}$ & \multicolumn{2}{l|}{$\begin{array}{l}\text { Total Cholesterol - mg/dl } \\
{[\text { Mean } \pm \text { SEM] }}\end{array}$} \\
\hline $\begin{array}{l}\text { Control group } \\
{[\text { D1] }}\end{array}$ & 6 & $101.83 \pm 11.03$ & Day-50 \\
\hline $\begin{array}{l}\text { Standard } \\
\text { group [G2] } \\
\text { Glibenclamide }\end{array}$ & 6 & $95.67 \pm 11.27$ \\
\hline $\begin{array}{l}\text { Trial-I [G3] } \\
\text { Kajutaka } \\
\text { Anacardium }\end{array}$ & 6 & $124.17 \pm 13.71$ & $113.00 \pm 13.52$ \\
\hline $\begin{array}{l}\text { Trial-II [G4] } \\
\text { Stevia }\end{array}$ & 6 & $105.00 \pm 15.50$ & $90.67 \pm 13.30$ \\
\hline
\end{tabular}

\section{DISCUSSION}

A plant is a highly complex material, which may have yen number of chemical constituents or compounds in it. It is amazing to note that our ancient seers were able to identify and utilize successfully for the many fold activities of the herb. The knowledge of folk medicines is enormous but has been lying dormant due to various reasons and is worthy of exploration.

The treatment of metabolic disorders like Diabetes where the decreased production of insulin or Improper utilization of Insulinkindled the search for new experimentally proven plants for their studies having maximum therapeutic activity and minimum side effects. 
On analysing the results, the study showed that the trial drug II S.rebaudiana is effective and trial drug A. occidentale is slightly effective in reducing the glucose level next to Glibenclamide.

The trial drug A. occidentale showed effective in reducing the triglyceride level followed by S. rebaudiana.

There is no significant difference found in reducing HDL and Total Cholesterol level among all the groups.

\section{CONCLUSION}

The present experimental study is in preliminary and in a limited number of wistar rats it needs an elaborate study on a large number of wistar rats to evaluate anti-diabetic activity. Along with the above parameters we can also include other parameters, like Insulin assay, urine analysis to assess glucose level, histology of pancreas and Glycosylated Hemoglobin (HbA1c) etc. of experimental animals. Elaborate clinical trials are required to evaluate the effects of these drugs on NIDDM based on other biochemical parameters.

\section{ACKNOWLEDGEMENT}

The authors are grateful to Dr H.R.Pradeep, Dr Sanjaya K.S., Prof Mulugu Vidyasagar, and Dr Sreedhar R.Pai for their timely suggestion and help.

Funding: No funding sources

Conflict of interest: None declared

Ethical approval: The study was approved by the Institutional Ethics Committee

\section{REFERENCES}

1. American Diabetes Association. Diagnosis and classification of diabetes mellitus. Diabetes care. 2006;29(1):S43.

2. Wild, Sarah. Global prevalence of diabetes estimates for the year 2000 and projections for 2030. Diabetes care. 2004;27(5):1047-53.
3. Gandjbakhch I, Leprince P, D'Alessandro C, Ouattara A, Bonnet N, Varvous S, et al. Coronary artery bypass graft surgery in patients with diabetes. Bull. Acad. Natl. Med. 2005;189:257-66.

4. Mota ML. Anti-inflammatory actions of tannins isolated from the bark of Anacardiumoccidentale. J. Ethnopharmacol. 1985;13:289-300.

5. Ojewole JA. Laboratory evaluation of the hypoglycemic effect of Anacardiumoccidentale Linn. (Anacardiaceae) stem-bark extracts in rats. Methods Find Exp. Clin. Pharmacol. 2003;25(3):199.

6. Pezzuto, John M. Metabolically activated steviol, the aglycone of stevioside, is mutagenic. Proceedings of the National Academy of Sciences. 1985;82(8):247882.

7. Megeji NW, Kumar JK, Singh V, Kaul VK, Ahuja, PS. Introducing Stevia rebaudiana. A natural ZeroCalorie sweetener, Curr. Cell sci. 2005;88(5):801-4.

8. Nakamura S, Tamura $Y$. Variation in the main glycosides of Stevia (Stevia rebaudiana Bertoni). Jpn J. Trop. Agric. 1985;29:109-16.

9. Melis MS. I Journal of Ethnopharmacology. 1995;47:129-34.

10. Lewis WH. Early uses of Stevia rebaudiana (Asteraceae) leaves as a sweetener in paraguay. Econ. Bot. 1992;46:336-7.

11. Toyomizu M, Sugiyama S, Jin RL, Nakatsu T. $\alpha$ glucosidase and aldose reductaseinhibitors: constituents of cashew, Anacardiumoccidentale, nut shell liquids. Phytother. Res. 1993;7:252-4.

12. Arya R, Babu V, Liyas M, Nasim KT. Phytochemical examination of the leaves of Anacardiumoccidentale. J. Ind. Chem. Soc. 1989;66:67-8.

13. Ivorra MD, D'Ocon MP, Paya M, Villar A. Antihyperglycemic and insulin release effects of $\beta$ sitosterol 3- $\alpha-\mathrm{D}$ glucoside and its aglucone $\beta$ sitosterol. Arch. I. Pharmacody. Ther. 1988;296:22431.

Cite this article as: Brijesh $\mathrm{K}$, Kamath $\mathrm{M}$.

Experimental evaluation of anti-hyperglycemic and hypolipidemic effects of stevia rebaudiana, anacardium occidentale on wistar rats. Int J Basic Clin Pharmacol 2016;5:2463-7. 